\title{
Comparative Research on the Traditional Teaching Method and the Situational Teaching Method of Children's Printmaking
}

\author{
Xie $\mathrm{Li}^{1}{ }^{*}, \mathrm{Li} \operatorname{Dan}^{2}$ \\ ${ }^{l}$ School of Pre-school Education, School of Pre-school Education of Chongqing University of Education, Chongqing \\ 400065, China \\ ${ }^{2}$ Chongqing Qijiang Experimental Kindergarten, Qijiang, Chongqing 400067, China \\ *Corresponding author: E-mail: xieli.0701@163.com
}

\begin{abstract}
Children's printmaking is an important part of children's art education. In order to explore suitable teaching methods for children's printmaking, this research randomly selected 10 children with equivalent printmaking skills for experimental research on traditional teaching method and situational teaching method in groups. The experimental results show that the teaching results of the two teaching methods are considerably different, and the results of using the situational teaching method are better than the traditional teaching method. Therefore, the situational teaching method is more suitable for the teaching of children's printmaking.
\end{abstract}

Keywords: teaching of children's printmaking; traditional teaching method; situational teaching method

\section{FOREWORD}

The children's printmaking course is a comprehensive course on the cultivation of children's painting and handicraft, which is in line with the general objective of children's art activities in the Early Learning and Development Guideline at 3-6 Years Old. According to the survey, many kindergartens in China currently offer printmaking courses. However, due to the influence of the tendency of primary schools, most of the printmaking courses in kindergartens adopt patterned traditional teaching method ${ }^{[1]}$. In the traditional teaching method, the children draw the print according to the teacher's demonstration and complete the tasks according to the steps of the teacher. Through imitation, although the children can complete a print in a short time, the long-term imitation may cause the children to form a mindset, which hinders the development of their creative abilities and other abilities. Finally, it is difficult for the children to complete a task independently without the guidance of the teacher ${ }^{[2]}$. Unlike the traditional teaching method, the situational teaching method has certain advantages in stimulating children's initiative and creativity, and can stimulate children's active exploration interest ${ }^{[3]}$. Specifically, the situational teaching method refers to that in the teaching process, the teacher introduces or creates a situation suitable for the content of the teaching in the form of questions or music that other children are willing to accept in the corresponding link of the teaching based on the teaching objectives according to the actual teaching situation (real or simulated) to stimulate children's enthusiasm for learning and trigger their emotional experience. It is a teaching method that guides young children to actively explore, learn new knowledge and new skills in a relaxing and happy teaching atmosphere, and transfer the learned knowledge and skills into practice, thereby achieving the best results of teaching and learning [4].

On the basis of summarizing the existing teaching experience, this research focuses on analysis of the teaching effects of the situational teaching methods and the traditional teaching method in the teaching of printmaking for children by the equivalent (or equal) group experiment, and exploration of the teaching method of printmaking suitable for children combining the characteristics of children's physical and mental development and the teaching objectives of printmaking through the comparison of the situational teaching method and the traditional teaching method to promote the scientific development of printmaking teaching for children.

\section{RESEARCH METHODS}

\subsection{Research object}

In order to avoid the influence of irrelevant factors, this research adopted the equivalent (or equal) group experiment method. 10 children of the same age were randomly selected in Chongqing, and divided into experimental group of situational teaching method and control group of traditional teaching method according to their ability level. The children with basically the same drawing and handcrafting abilities were grouped to reduce inter-group differences. The two teaching groups use the same teaching theme, and are taught by the same teacher by different teaching methods. At the same time, we agreed 
with the parents on not giving children as experimental objects additional training related to drawing and handcraft and family counseling that help improve children's printmaking skills to ensure better control of the impact of irrelevant variables on the experimental results.

\subsection{Research tools}

In this experiment, based on the children's existing experience and physical and mental development characteristics, four themes have been selected for teaching, namely, Vase, Little Goldfish, House, and Drawing Spring. The instructor conducts theme-based teaching once a week for approximately 30 minutes, which lasts for four weeks.
In the course of the experiment, after teaching is completed, the researcher will provide blow molding paper, paint, pencil, roller, A4 paper, newspaper and other materials that are easily accessible in life for the children. According to the established scoring standards, the results of the printmaking of the children serve as the basis for recording the experimental data.

Considering that the teaching of printmaking involves cultivating children's abilities in painting and handcraft, the painting evaluation standard table and handcraft evaluation standard table for children in this experiment are formulated in this research with reference to the evaluation standard for handcraft of children established by the scholar Xia Xiaoting ${ }^{[5]}$. See Table 1 and Table 2 for details.

Table 1 Evaluation Standard Table of Children's Printmaking-Handcraft

\begin{tabular}{|c|c|c|c|}
\hline Grade & $\begin{array}{c}\text { Materials and skills } \\
\mathbf{( 3 0} \text { points) }\end{array}$ & $\begin{array}{c}\text { Shape and modification } \\
\mathbf{( 3 0} \text { points) }\end{array}$ & $\begin{array}{c}\text { Creation and thinking } \\
\text { (40 points) }\end{array}$ \\
\hline A & Appropriate & Strong modificability & Ingenious design \\
\hline B & Relatively appropriate & General modificability & Ordinary design \\
\hline C & Not appropriate & Less modificability & Flat design \\
\hline D & Cannot apply & Basically no modification & $\begin{array}{c}\text { Cannot design } \\
\text { independently }\end{array}$ \\
\hline
\end{tabular}

Note: The scoring criteria for materials and skills, shape and modification dimensions are: Grades A (24-30 points), B (16-23 points), $\mathrm{C}$ (8-15 points), and D (0-7 points). The scoring criteria for the creation and thinking dimensions are: Grades A (30-40 points), B (20-29 points), C (10-19 points), and D (0-9 points)

Table 2 Evaluation Standard Table of Children's Printmaking-Painting

\begin{tabular}{|c|c|c|c|c|}
\hline Grade & $\begin{array}{c}\text { Color } \\
(\mathbf{2 0} \text { points) }\end{array}$ & $\begin{array}{c}\text { Structure } \\
\mathbf{( 2 0} \text { points })\end{array}$ & $\begin{array}{c}\text { Shape } \\
\mathbf{2 0} \text { points })\end{array}$ & $\begin{array}{c}\text { Creativity } \\
\mathbf{( 4 0} \text { points) }\end{array}$ \\
\hline $\mathrm{A}$ & Uniform painting & Form simple picture & Clear outline & Unique ideas \\
\hline $\mathrm{B}$ & $\begin{array}{c}\text { Not very uniform } \\
\text { painting }\end{array}$ & $\begin{array}{c}\text { Cannot form simple } \\
\text { picture }\end{array}$ & Not clear outline & Flat design \\
\hline $\mathrm{C}$ & Not uniform painting & Independent object & Incomplete outline & Strong \\
& & &
\end{tabular}

Note: The scoring criteria for color, structure, and shape dimensions are: Grades A (14-20 points), B (7-13 points), and C (0-6 points). The scoring criteria for creativity dimension are: Grades A (27-40 points), B (13-26 points), and C (0-13 points)

\section{RESULTS AND ANALYSIS}

\subsection{Dimensions of children's printmaking- painting}

The experimental results show that the children's scores in drawing ability have gradually increased in the four weeks of teaching no matter they are in the traditional teaching group or the situational teaching group. In the color dimension, the changes in results of the two teaching methods are basically the same, and the total score of the situational teaching group is slightly higher than that of the traditional teaching group. In the structure dimension, the scores of the situational teaching method in the later stage of teaching exceed that of the traditional teaching method. In the shape dimension, the scores of the traditional teaching group obviously exceed that of the situational teaching group. In the creativity dimension, the scores of situational teaching group are higher than that of the traditional teaching group. See Table 3 for details. 
Table 3 Scores of Each Dimension of Painting of Traditional Teaching Group and Situational Teaching Group in the Painting Dimension

\begin{tabular}{|c|c|c|c|c|c|c|c|c|c|c|c|c|c|c|c|c|}
\hline $\begin{array}{l}\text { Evaluation } \\
\text { Criteria } \\
\text { Teaching } \\
\text { Method } \\
\end{array}$ & \multicolumn{4}{|c|}{ Color } & \multicolumn{4}{|c|}{ Structure } & \multicolumn{4}{|c|}{ Shape } & \multicolumn{4}{|c|}{ Creativity } \\
\hline \multirow{5}{*}{$\begin{array}{l}\text { Traditional } \\
\text { Teaching } \\
\text { Group }\end{array}$} & 10 & 12 & 16 & 16 & 13 & 15 & 16 & 17 & 15 & 16 & 18 & 19 & 19 & 23 & 23 & 28 \\
\hline & 10 & 13 & 15 & 18 & 12 & 14 & 14 & 16 & 13 & 16 & 18 & 18 & 22 & 22 & 24 & 25 \\
\hline & 13 & 13 & 15 & 16 & 15 & 16 & 18 & 18 & 11 & 17 & 18 & 19 & 22 & 24 & 25 & 28 \\
\hline & 12 & 16 & 16 & 17 & 14 & 15 & 15 & 16 & 10 & 15 & 19 & 19 & 26 & 26 & 29 & 30 \\
\hline & 9 & 12 & 12 & 13 & 10 & 14 & 14 & 16 & 12 & 15 & 18 & 18 & 21 & 23 & 24 & 26 \\
\hline \multirow{5}{*}{$\begin{array}{l}\text { Situational } \\
\text { Teaching } \\
\text { Group }\end{array}$} & 11 & 12 & 15 & 16 & 13 & 16 & 16 & 17 & 12 & 14 & 14 & 19 & 21 & 24 & 26 & 29 \\
\hline & 9 & 11 & 15 & 17 & 11 & 12 & 14 & 16 & 10 & 12 & 15 & 16 & 20 & 22 & 26 & 27 \\
\hline & 12 & 13 & 18 & 19 & 16 & 16 & 18 & 19 & 10 & 12 & 17 & 15 & 24 & 25 & 26 & 29 \\
\hline & 12 & 14 & 15 & 18 & 15 & 18 & 19 & 18 & 9 & 11 & 13 & 14 & 26 & 26 & 27 & 30 \\
\hline & 10 & 11 & 15 & 15 & 11 & 15 & 15 & 16 & 10 & 15 & 16 & 16 & 22 & 24 & 25 & 25 \\
\hline
\end{tabular}

\subsection{Dimensions of children's printmaking- handcraft}

The experimental results show that the children's scores in handcraft ability have gradually increased in the four weeks of teaching of the traditional teaching group and the situational teaching group. In terms of materials and skills, shape and modification, there is no obvious difference between the traditional teaching group and the situational teaching group. But in terms of creativity and thinking, the scores of the situational teaching group are obviously higher than that of the traditional teaching group. See Table 4 for details.

Table 4 Scores of Each Dimension of Handcraft Traditional Teaching Group and Situational Teaching Group in the Handcraft Dimension

\begin{tabular}{|c|c|c|c|c|c|c|c|c|c|c|c|c|}
\hline $\begin{array}{l}\text { Evaluation } \\
\text { Criteria } \\
\text { Teaching } \\
\text { Method } \\
\end{array}$ & \multicolumn{4}{|c|}{ Materials and Skills } & \multicolumn{4}{|c|}{ Shape and Modification } & \multicolumn{4}{|c|}{ Creativity and Thinking } \\
\hline \multirow{5}{*}{$\begin{array}{c}\text { Traditional } \\
\text { Teaching } \\
\text { Group }\end{array}$} & 21 & 24 & 24 & 25 & 20 & 21 & 23 & 26 & 22 & 24 & 25 & 27 \\
\hline & 20 & 23 & 24 & 25 & 20 & 23 & 23 & 24 & 18 & 19 & 24 & 25 \\
\hline & 19 & 22 & 24 & 27 & 22 & 24 & 25 & 28 & 24 & 24 & 26 & 26 \\
\hline & 23 & 23 & 24 & 25 & 18 & 22 & 25 & 26 & 25 & 24 & 25 & 26 \\
\hline & 22 & 22 & 24 & 27 & 20 & 20 & 23 & 25 & 22 & 21 & 22 & 24 \\
\hline \multirow{5}{*}{$\begin{array}{c}\text { Situational } \\
\text { Teaching } \\
\text { Group }\end{array}$} & 22 & 23 & 26 & 26 & 20 & 22 & 25 & 25 & 21 & 24 & 29 & 32 \\
\hline & 21 & 22 & 25 & 25 & 19 & 21 & 23 & 26 & 20 & 22 & 25 & 32 \\
\hline & 20 & 22 & 23 & 26 & 23 & 25 & 25 & 29 & 25 & 25 & 27 & 30 \\
\hline & 22 & 24 & 26 & 27 & 20 & 24 & 25 & 27 & 25 & 25 & 26 & 30 \\
\hline & 20 & 21 & 26 & 28 & 19 & 22 & 25 & 26 & 22 & 23 & 27 & 33 \\
\hline
\end{tabular}

\subsection{Test of differences between situational teaching group and traditional teaching group}

For the convenience of statistics, this research adopts the ttest of the average scores of handwork and painting of the two groups of children for the differences between the two teaching methods. In this experiment, the four scores of the situational teaching group and the traditional teaching group are respectively tested by $t$ test to determine whether there were obvious differences in the results of the two teaching methods. The data analysis results show that there is no obvious difference in the first three times, and there are obvious differences between the situational teaching group and the traditional teaching group at the forth time, indicating that after 4 weeks of teaching, the experimental group's results have statistically obvious differences with the control group. See Table 5 for details. 
Table 5 Independent Sample Test Table for Average Score of Situational Teaching Method Group and Traditional Teaching Method Group (t-test)

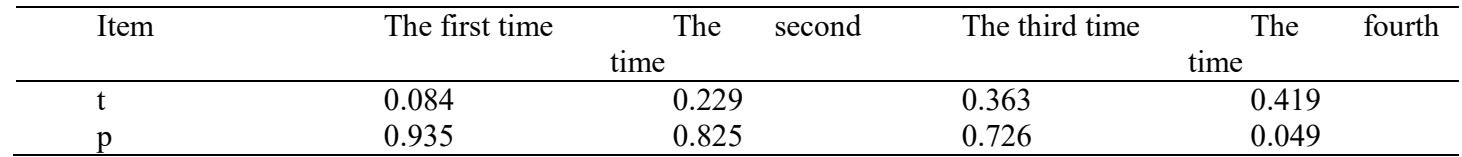

\section{DISCUSSION}

Both teaching methods promote the development of children's printmaking ability to a certain extent. For the "color" dimension, the results of the two teaching methods have basically the same change trend, indicating that the traditional teaching method and the situational teaching method have little difference in improving color results. The main reason is that children's mastery of color is gradually formed in the process of long-term experience accumulation, and the sensitivity to color is gradually formed. Short-term teaching cannot rapidly improve their color sensitivity. For the "structure" dimension, the scores of the traditional teaching method at the first and second times are higher than that of the traditional teaching method, but after the third time, the scores of the situational teaching group improve faster than that of the traditional teaching group, indicating that the traditional teaching method is better than the situational teaching method in improving short-term results, but from the perspective of the growth and development of children, the situational teaching method is more suitable for the development of their potential. For the "shape" dimension, the results of the control group are better than that of the experimental group. The children in the control group express the shape more realistically, because their imitation ability is enhanced relatively faster, and they grasp the shape more accurately. This is because in the process of printmaking teaching, the children in the control group pay more attention to how to imitate the shape of the object demonstrated by the teacher, while the children in the experimental group focus on exploring the way to paint. For the "creativity" dimension, the situational teaching method is superior to the traditional teaching method in scores because the children understand the theme more profoundly in the theme teaching activities. The situational teaching method does not stay in the imitation stage, and it also combines painting with life to fully and boldly express the true thoughts of children, indicating that the situational teaching method can promote children's independent creativity more efficiently.

For the "materials and skills" dimension, there is no obvious difference in results between the traditional teaching group and the situational teaching group after the teaching for the first time, but with the increase of teaching, the results of the situational teaching method are better than that of the traditional teaching method, indicating that the situational teaching method can better stimulate their potential after they have mastered the basic material selection and skills. For the "shape modification" dimension, the traditional teaching method and the situational teaching method are not much different at the beginning. The results of the traditional teaching method in the second week are even better than that of the situational teaching method, but after the third week, the results of the situational teaching method are improved obviously, indicating that the situational teaching method can effectively improve the shape modification ability of children. It may be because under the guidance of the traditional teaching method, children learn some basic shapes and typical decoration methods by means of memory, so they can achieve higher results in the teaching activities of the first two times; but in the later period, with the gradual deepening of the teaching content and the increase in difficulty, the advantages of the traditional teaching method gradually disappear. For the "creativity and thinking" dimension, the results of the situational teaching method are obviously higher than that of the traditional teaching method. This is because the teachers create classroom situations in the teaching process through the development of games, storytelling and performance, problem guidance, etc., which mobilizes the children's interest, fills the gaps in teaching activities, and enhances children's emotional experience by stimulating their senses, enabling children to perceive prints in the context, thereby attracting children to actively participate in print teaching activities.

\section{RESEARCH CONCLUSION}

Generally speaking, after a 4-week printmaking teaching experiment on children, we can see from the experimental data that both the situational teaching method and the traditional teaching method can improve children's printmaking ability. However, there is a significant different between the two teaching methods with the extension of teaching time, as well as the overall scores of the situational teaching method group are higher than that of the traditional teaching group. As for the teaching method, the situational teaching method will be more conducive to children's printmaking skill, especially in developing children's potential, stimulating active exploration interest, and enhancing emotional experience. Therefore, it is suggested that situational teaching method can be timely integrated into daily printmaking teaching, to make up for the shortcomings of traditional teaching method in the subsequent children's printmaking teaching procedures, and so that improve the effect of children's printmaking teaching, cultivate young children in creative ability and pioneering ability. 


\section{FUND PROGRAM}

Project Source: School Project of Chongqing University of Education: Research on the Flow Mechanism of Early Education Teachers of Infants and Young Children of 0-3 Years Old (KY201913C)

\section{REFERENCES}

[1] Bao Longhui. (2017) On the Unique Role of Children's Printmaking in Children's Education. Course Education Research. 19: 201-202.

[2] Yu Shuzhen. (2014) Analysis of Situational Teaching in Kindergartens. Education Exploration, 09: 141-142.

[3] Li Rufang. (2018) An Analysis of the Problems and Strategies of Children's Printmaking Teaching. Education Week, 06: 38-39.

[4] Xu You. (2012) Application Research of Situational Teaching in Kindergartens. Southwest University, Chongqing.

[5] Xia Xiaoting. (2014) Study on the Teaching of Handcraft Activities for Children of 5-6 Years Old. Wenzhou University, Zhejiang. 